\title{
Proteasome Adapter and Scaffold Protein ECM29
}

National Cancer Institute

\section{Source}

National Cancer Institute. Proteasome Adapter and Scaffold Protein ECM29. NCI

Thesaurus. Code C158580.

Proteasome adapter and scaffold protein ECM29 (1845 aa, 204 kDa) is encoded by the human ECPAS gene. This protein plays a role in proteasome localization and assembly. 